\title{
Organization and functioning of the health gym program in the city of Camaragibe-PE
}

\section{Organização e funcionamento do programa academia da saúde em Camaragibe-PE}

\section{AUTHOR'S \\ Juliana D Fátima Lira Lucena ${ }^{1,2}$ (D) \\ Leonardo Rodrigo de Luna Saturnino ${ }^{1,3}$ \\ Vilde Gomes de Menezes 5 (D) \\ Wallacy Milton do Nascimento Feitosa ${ }^{1,3,5}$ (D) \\ Flávio Renato Barros da Guarda ${ }^{1,4,5}$ (D) \\ 1 Study Group on Policies of Health, Sports and Leisure. Recife, Pernambuco. Brazil. \\ 2 University of Pernambuco. Department of Physical Education. Recife, Pernambuco. Brazil. \\ 3 Recife Military School. Physical Education Section. Recife, Pernambuco. Brazil. \\ 4 Federal University of Pernambuco. Vitória de Santo Antão, Pernambuco. Brazil. \\ 5 Post Graduation Program of the Federal \\ University of Pernambuco. Department of Physical \\ Education. Recife, Pernambuco. Brazil}

\section{CORRESPONDING}

Juliana D Fátima Lira Lucena

julianaliralucena@gmail.com

Vila Nossa Senhora de Lourdes, 109

Estância, Recife, Pernambuco, Brasil.

CEP: 50865-140.

DOI

10.12820/rbafs.v.22n6p584-88

\section{(ब) $\Theta \Theta$}

Copyright: This is an open-access article distributed nder the terms of the Creative Commons Attribution License ${ }^{\circledR}$, which permits unrestricted use, distribution, and reproduction in any medium, provided that the original author and source are credited.

\begin{abstract}
The evaluation of health policies and programs is an important tool for decision-making. Among the instruments used for this purpose, the Logical Model stands out, establishing a visual reference regarding the interaction among the inputs, activities and expected results of an intervention. The present study aimed to evaluate the organization of actions and the functioning of the Programa Academia da Saúde (PAS - Health Gym Program) in the city of Camaragibe, Pernambuco state, Northeastern Brazil, using a logical model. Program actions were in line with some guidelines established by the Brazilian Ministry of Health services in relation to other primary care services and promotion of the adoption of active lifestyles by the population. However, they do not comply with the recommendations for work shifts and the professionals'workload at the centers. Camaragibe has the potential to enlarge the scope of multi-professional approaches aimed at comprehensive care.
\end{abstract}

Keywords: Health evaluation; Health programs; Primary health care; Brazilian Public Health System; Brazil

\section{RESUMO}

A avaliação de políticas e programas de saúde configura-se como uma importante ferramenta para a tomada de decisão. Entre os instrumentos utilizados para esse fim, destaca-se o Modelo Lógico, o qual estabelece uma referência visual a respeito da articulação entre os insumos, atividades e resultados esperados para uma intervenção. O objetivo deste estudo foi avaliar a organização das ações e o funcionamento do Programa Academia da Saúde (PAS) no municipio de Camaragibe (Pernambuco) utilizando um modelo lógico. Observou-se que as ações do PAS alinham-se a algumas diretrizes estabelecidas pelo Ministério da Saúde quanto à articulação com outros serviços da atenção primária e incentivo à adoção de estilos de vida ativos por parte da população, porém, não atendem as recomendaçôes quanto aos turnos de funcionamento e carga horária dos profissionais que atuam no polo. As açôes do PAS em Camaragibe têm potencial para ampliar o escopo de abordagens multiprofissionais com vistas à integralidade do cuidado.

Palavras-chave: Avaliação em saúde; Programas da saúde; Atenção primária à saúde; Sistema Único de Saúde; Brasil.

\section{Introduction}

The evaluation of health programs is indicated as an essential practice for the process of decision-making and improvement of interventions aimed at the population ${ }^{1}$. Costa et al. ${ }^{2}$ emphasized that the assessment practice enables the identification of the effectiveness of interventions and the need to include specific and diverse activities, thus enabling the (re)organization of actions.
Therefore, the use of assessment strategies can be an important tool for the monitoring and assessment of physical activity programs, such as the Programa Academia da Saúde (PAS - Health Gym Program), aimed at contributing to health promotion and the production of care and health lifestyles in the population through the building or implementation of public spaces with qualified professionals and infrastructure ${ }^{3}$. 
In this sense, the use of tools that enable visualizing the relationship between components, activities, objectives and results expected for the Health Gym Program would allow both the systematic follow-up of actions and the redirection of procedures for the qualification of such intervention. One of the tools used in this process is the Logical Model (LM), an instrument aimed at documenting the description and analysis of contextual factors that interfere with program activities $^{4}$, as it enables the visualization of what must be measured and its contribution to the expected results of an intervention. Additionally, the use of the LM enables the establishment of the relationship between resources and actions, facilitating the understanding and scope of the program objectives ${ }^{5}$.

Although significantly contributing to the decision-making process in terms of management and provision of health programs ${ }^{1}$, the incorporation of service routine assessment procedures is not a regular practice yet ${ }^{5}$. Thus, the identification of the limits and possibilities of a physical activity (PA) program can help to improve the development of actions and provide evidence of elements that guarantee quality services ${ }^{6}$, promoting the analysis of its impact on the organization and operationalization of health services ${ }^{7}$.

In this sense, the present study aimed to assess the organization of actions and the functioning of the Camaragibe Health Gym Program according to a logical model.

\section{Organization}

Camaragibe is located in the Recife Metropolitan Area (RMA), the sixth most populous one in Pernambuco state with 156,361 inhabitants, ranking $11^{\text {th }}$ in terms of demographic growth rate in this state. Due to its proximity to the capital city, many people live in $\mathrm{Ca}^{-}$ maragibe and work in the capital and, consequently, its growth is disorganized and irregular ${ }^{8}$. The health service network is comprised of 55 establishments, of which 46 are public and nine are private. Moreover, its sanitary sewage rate is $40.5 \%$ and death rate 13.3 deaths per 1,000 inhabitants ${ }^{8}$. Its epidemiological profile is characterized by high prevalence's of circulatory system diseases, diabetes and external causes ${ }^{9}$.

Aiming to increase the scope of Primary Care Actions (PCA), the health department implemented a Health Gym Program center in the community of Timbi, in April 2014, the district where the majority of the population lives ${ }^{8}$. Program activities are held in the Açude Santa Rita de Cássia Park, where the following group activities are performed: dance lessons, guided walks, functional exercise sessions, recreational and sports activities, popular games, localized exercises, stretching and resistance training. These activities are performed from Mondays to Fridays with the participation of older adults, adults and adolescents living in the community and neighboring districts. The planning and guidance of activities are performed by a physical education professional (PEP) under the supervision of a nursing professional. These professionals work for 20 hours per week at the PAS site in Camaragibe and Unidades de Saúde da Família (USF - Family Primary Care Units), associated with the Núcleo de Apoio à Saúde da Família (NASF - Family Health Support Teams), as shown in Table 1.

\section{Functioning}

At the São Francisco Primary Health Care Unit, located within the scope of the PAS site, hypertensive and diabetic users are divided into two groups that participate in activities supervised by physical education

Table 1 - Activities of the Health Gym Program, Timbi center, city of Camaragibe, Pernambuco, Brazil, 2017.

\begin{tabular}{|c|c|c|c|}
\hline Activity & Description & Location & Frequency \\
\hline Group activities & $\begin{array}{l}\text { Gymnastics, stretching, dancing, } \\
\text { body expression, popular games, } \\
\text { leisure activities, guided walks, } \\
\text { resistance exercises }\end{array}$ & Açude Santa Rita de Cássia Park & $\begin{array}{l}\text { Mondays through Fridays, from } 5: 00 \mathrm{pm} \\
\text { to } 7: 00 \mathrm{pm}\end{array}$ \\
\hline $\begin{array}{l}\text { Service for hypertensive and } \\
\text { diabetic users }\end{array}$ & $\begin{array}{l}\text { Talks, educational games and movies } \\
\text { related to the treatment of diseases } \\
\text { and promotion of physical activity } \\
\text { practice }\end{array}$ & USF São Francisco & Wednesdays from $2: 00 \mathrm{pm}$ to $4: 30 \mathrm{pm}$ \\
\hline $\begin{array}{l}\text { Interaction with NASF } \\
\text { professionals }\end{array}$ & $\begin{array}{l}\text { Analysis of strategies and } \\
\text { interventions suitable for users }\end{array}$ & USF Timbi I & Mondays from 2:00pm to $4: 00 \mathrm{pm}$ \\
\hline $\begin{array}{l}\text { Educational actions with NASF } \\
\text { professionals }\end{array}$ & $\begin{array}{c}\text { Group discussions, talks, educational } \\
\text { activities and games }\end{array}$ & Açude Santa Rita de Cássia Park & $\begin{array}{l}\text { Once a month at the time of group } \\
\text { activities }\end{array}$ \\
\hline $\begin{array}{l}\text { Events integrated with the NASF } \\
\text { team and Health Department }\end{array}$ & $\begin{array}{l}\text { Gymnastics, clinical guidance, } \\
\text { capillary blood sugar and blood } \\
\text { pressure testing }\end{array}$ & $\begin{array}{c}\text { Açude Santa Rita de Cássia Park } \\
\text { and/or USF }\end{array}$ & Random actions \\
\hline
\end{tabular}


professionals from the USF and NASF, every 15 days. The following activities are included: talks about health issues, educational games, movies related to healthy eating, the importance of practicing physical activities, knowledge about medications used in the treatment of certain diseases, and stress management, among other contents. Stretching sessions lasting 30 minutes each stood out, emphasizing the importance of regular PA practice and subsequent invitation for users to participate in activities at the center.

NASF professionals meet weekly to analyze clinical cases of users, aiming to discuss adequate strategies and interventions for each individual. Additionally, a team professional goes to this center every month to organize discussion groups about health-related themes. The Timbi site uses the following materials: PET bottles with water/sand as weights for exercises, balls, hoops and speak- ers as equipment for the development of daily activities.

The strategies developed at the Açude Park and USF São Francisco includes an average of 50 users per activity. Moreover, the Camaragibe Health Gym Program aims to facilitate social interaction and chronic non-communicable disease (CND) prevention and care, as described in the logical model below.

\section{Discussion}

The actions developed in the Health Gym Program in Camaragibe are similar to those performed in other community physical activity programs and they seem to meet the Program guidelines to promote the adoption of active lifestyles by the population ${ }^{10}$. However, in terms of work shifts when the program functions and working hours of physical education professionals, the PAS does not meet the recommendations of the pro-

\section{RESOURCES}

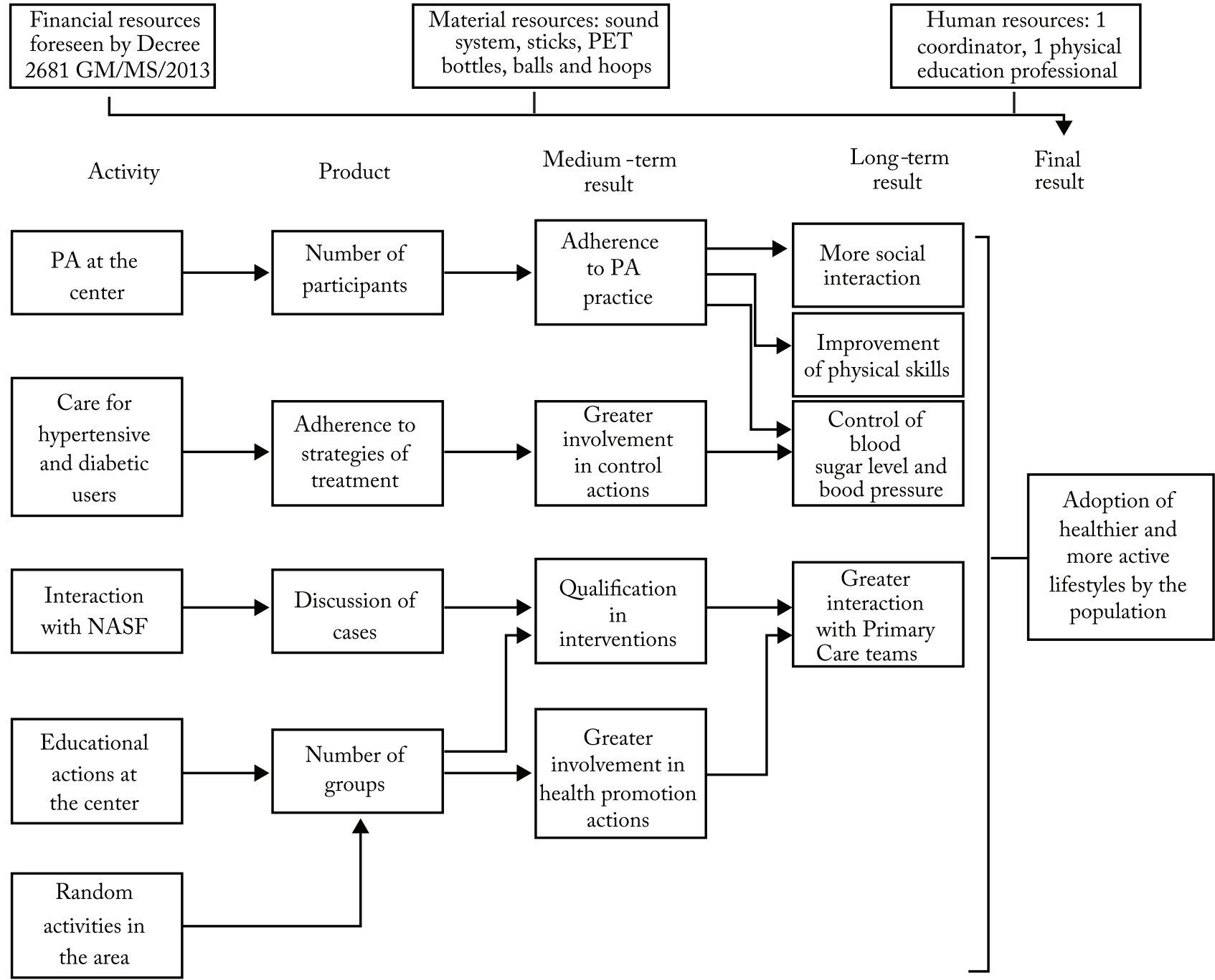

Figure 1 - Logical Model of the Health Gym Program in the city of Camaragibe, Pernambuco, Brazil, 2017. PA: physical activity; NASF: Family Health Support Teams. 
gram guidelines. These guidelines show that activities must be performed during two different work shifts and include the presence of a professional working 40 weekly hours or two working 20 weekly hours each ${ }^{11}$.

The development of actions in partnership with USF and NASF teams shows the interaction between the program and the city's Primary Care Network, aiming to achieve integrality of health care. This interaction enables the increase in the scope of multiprofessional approaches to deal with different health problems in this area, as previously observed in studies on PAS in other Brazilian cities ${ }^{12}$.

Educational activities about the benefits of the adoption of healthy behavior are considered to be important strategies for health promotion ${ }^{13}$. In this sense, the development of talks, educational games and dynamics in Camaragibe is an important tool to reduce program users' exposure to risk behavior associated with NCD. However, these actions do not regularly cater for the same population, as they are performed in the waiting room of the USF and particularly include users seeking this service on the day when interventions are conducted. This lack of continuity of actions of health education was also observed in other physical activity programs developed in the Recife Metropolitan Area ${ }^{11}$.

A positive aspect of the Camaragibe PAS functioning is the development of Singular Therapeutic Projects (STP) based on the discussion of cases in weekly meetings with the Primary Care teams. The development of STPs is recommended as an intervention strategy on this level of organization of the health system and contribute to processes of change in health practices, in addition to diversifying the provision of services ${ }^{14}$.

The material resources used in the center are improvised, especially with the use of PET bottles as an implement for the performance of resistance exercises, thus restricting the possibilities of adequacy and progressive increase in loads ${ }^{11}$. However, studies indicate that this practice is common in community programs of physical activities ${ }^{12}$.

The preparation of logical models for PA programs is recommended by the Centers for Disease Control and Prevention (CDC) as a supporting tool for decision-making ${ }^{15}$. The logical model of PAS in Camaragibe was developed by the physical education professional and Primary Care coordinator in this city, aiming to establish a reference for the monitoring and assessment of such intervention. It enables the observation of the interaction among the resources required for the development of actions; activities performed and expected results, aiming to describe the causal path for Program actions to meet their goals through the structure-process-result triad ${ }^{1}$.

\section{Final considerations}

The Camaragibe PAS partially meets the guidelines recommended by the Brazilian Ministry of Health for this intervention, with an emphasis on the provision of health promotion and care production activities on a multiprofessional basis, interaction with Primary Care teams and incentive for physical activity practice, which can improve actions and promote important results about individual and community health, especially in terms of exposure to risk behavior for CND. However, adjustments must be made to the number of working hours, materials and program functioning periods.

Logical Models contribute to both the organization and follow-up of the routine dynamics of a service and the planning, management and development of assessment studies in the academic field. In this sense, the construction of this tool enables one to visualize how the program is organized in the area and how the activities developed are in agreement or disagreement with the guidelines recommended for such intervention.

\section{Conflito de interesses}

The authors declare no have conflict of interest.

\section{Contribuição dos autores}

Lucena JDFL, participated in the literature search, data analysis and interpretation, article writing and final approval of the version to be published. Saturnino LRL, participated in the analysis and interpretation of the data, writing of the article and final approval of the version to be published. Menezes VG, participated in the analysis and interpretation of the data, relevant critical review of the intellectual content and final approval of the version to be published. Feitosa WMN, participated in the analysis and interpretation of the data, relevant critical revision of the intellectual content and final approval of the version to be published. Guarda $\mathrm{FRB}$, participated in the design and project, critical review relevant intellectual content and final approval of the version final.

\section{Reference}

1. Hartz ZMA. Avaliação em saúde: dos modelos conceituais à prática na análise da implantação de programas. Rio de Janeiro: Editora FIOCRUZ, 1 ed. 1997.

2. Costa PHAd, Colugnati FAB, Ronzani TM. Avaliação de serviços em saúde mental no Brasil: revisão sistemática da literatura. Ciênc Saúde Coletiva. 2015;20:3243-53.

3. Ministério da Saúde (Brasil). Portaria no 2.681, de 7 de novembro de 2013. Redefine o Programa Academia da Saúde no âmbito do Sistema Único de Saúde (SUS). Diário Oficial da União 8 nov 2013; Seção 1. 
4. Rover MRM, Vargas-Pelaez CM, Manzini F, Mendes SJ, Farias MR, Leite SN. Modelo Teórico e Lógico para avaliação da capacidade de gestão do Componente Especializado da Assistência Farmacêutica. Rev. Gestão \& Saúde. 2016;07(01):191-10.

5. Cassiolato M, Gueresi S. Como elaborar Modelo Lógico: roteiro para formular programas e organizar avaliação. Brasília: IPEA; 2010. Disponível em:http://www.ipea.gov. br/portal/images/stories/PDFs/100924_notatec6disoc.pdf. Acesso em: 16 set 2017.

6. Tanaka OY, Melo C. Uma proposta de abordagem transdisciplinar para avaliação em Saúde. Interface - Comunic, Saúde, Educ. 2000;4:113-8.

7. Miclos PV, Calvo MCM, Colussi CF. Avaliação do desempenho da Atenção Básica nos municípios brasileiros com indicador sintético. Saúde em Debate. 2015;39:984-96.

8. Brasil. Instituto Brasileiro de Geografia e Estatística. IBGE. Censo Demográfico 2010. Disponível em: https://cidades. ibge.gov.br/brasil/pe/camaragibe/panorama. Acesso em: 11 dezembro 2017.

9. Brasil. Ministério da Saúde. Departamento de Informática do Sistema Único de Saúde. Estatísticas de morbidade hospitalar no município de Camaragibe-PE. Disponível em: http://tabnet.datasus.gov.br/cgi/tabcgi.exe?sih/cnv/nrpe.def. Acesso em: 13 Dez 2017.

10. Malta DC, Silva Jr JBd. O Plano de Ações Estratégicas para o Enfrentamento das Doenças Crônicas Não Transmissíveis no Brasil e a definição das metas globais para o enfrentamento dessas doenças até 2025: uma revisão. Epidemiol. Serv. Saúde. 2013;22:151-64.
11. Guarda FRB, Silva RN, Feitosa WMN, Neto PMS, Júnior JLACA. Caracterização das equipes do Programa Academia da Saúde e do seu processo de trabalho. Rev Bras Ativ Fis Saúde; 2015;20(6):638-40.

12. Rodrigues JD, Ferreira DKS, Junior JCF, Caminha IO, Florindo AA, Loch MR. Perfil e atuação do Profissional de Educação Física nos Núcleos de Apoio à Saúde da Família na região metropolitana de João Pessoa, PB. Rev Bras Ativ Fis Saúde. 2015;20(4):352-65.

13. Guarda FRB, Silva RN, Silva SM, Santana PR. A atividade física como ferramenta de apoio às ações da Atenção Primária à Saúde. Rev Bras Ativ Fís Saúde. 2014;19(2):265-70.

14. Brasil. Ministério da Saúde. Secretaria de Atenção à Saúde. Departamento de Atenção Básica. Diretrizes do NASF: Núcleo de Apoio a Saúde da Família / Ministério da Saúde, Secretaria de Atenção à Saúde, Departamento de Atenção Básica. - Brasília: Ministério da Saúde, 2010.

15. U.S. Department of Health and Human Services. Physical Activity Evaluation Handbook. Atlanta: Centers for Disease Control and Prevention; 2002.

\section{Quote this article as:}

